\title{
Does Risk Preferences Executive Influence the Relationship between Corporate Social Responsibility Disclosure and Tax Avoidance?
}

\author{
Wisnu Dewi Fitriyani \\ wdewif18@gmail.com \\ Accounting Study Program, Faculty of Business \\ President University, Cikarang, Indonesia \\ Vita Elisa Fitriana \\ vita.elisa@president.ac.id \\ Accounting Study Program, Faculty of Business \\ President University, Cikarang, Indonesia
}

\begin{abstract}
This research aims to examine the influence of the corporate social responsibility (CSR) disclosure towards the tax avoidance by considering corporate governance which is risk preferences executive. The sample that used in this study are 55 manufacturing companies listed in Indonesia Stock Exchange period 2014-2017. The researcher used regression analysis for analyzing the data. The result shows that corporate social responsibility disclosure using the proxy of Global Reporting Initiative G4.0 significantly influences tax avoidance. Risk preferences executive as the indipendent variable and moderating variable between corporate social responsibility disclousre and tax avoidance both has significant influence. The risk preferences executive as moderating variable in this study reveals a positive significant influence that proves the risk preferences executive strengthen the relationship between corporate social responsibility disclosure and tax avoidance.
\end{abstract}

Keywords: Corporate Social Responsibility Disclosure, Risk Preferences Executive, Tax Avoidance.

\begin{abstract}
Abstrak
Penelitian ini bertujuan untuk menguji pengaruh pengungkapan tanggung jawab sosial perusahaan (CSR) terhadap penghindaran pajak dengan mempertimbangkan tata kelola perusahaan beupa preferensi risiko eksekutif. Sampel yang digunakan dalam penelitian ini adalah 55 perusahaan manufaktur yang terdaftar di Bursa Efek Indonesia periode 2014-2017. Analisis data menggunakan regresi linier berganda. Hasil penelitian menunjukkan bahwa pengungkapan tanggung jawab sosial perusahaan dengan proksi Global Reporting Initiative G4.0 berpengaruh signifikan terhadap penghindaran pajak. Preferensi risiko eksekutif sebagai variabel indipenden dan variabel moderasi antara pengungkapan tanggung jawab sosial perusahaan dan penghindaran pajak memiliki pengaruh yang signifikan. Preferensi risiko eksekutif sebagai variabel moderasi dalam penelitian ini menunjukkan pengaruh signifikan positif yang membuktikan bahwa eksekutif preferensi risiko memperkuat hubungan antara pengungkapan tanggung jawab sosial perusahaan dengan penghindaran pajak.
\end{abstract}

Kata kunci: pengungkapan tanggung jawab sosial, preferensi risiko eksekutif, penghindaran pajak 


\section{INTRODUCTION}

As a good citizen, we have to obey the government rules include the tax rules. Based on General Provisions and Tax Procedures, tax is managed on Article 23 that stated tax is the mandatory contribution to the state by any individual or corporate as the tax subject which implemented in view of the law with no direct benefit consequently and is utilized for the most maximum welfare of peoples. One of the tax function is the budgeter function, implies that the tax can be utilized as an instrument to raise the income for the state spending need. In other words, the tax is one of the source of funding for Indonesia.

In the period of 2014-2018, the government has succeeded in increasing tax revenues from IDR 1,146.9 trillion in 2014 to IDR 1,618.1 trillion in 2018. During this period, total tax revenues tend to be increase (Ministry of Finance of the Republic of Indonesia, 2018), it means that how important the tax is for the government and also for the economic development of Indonesia. Taxes are the backbone of state revenues. Therefore, it is important for the government to know the factors that influence tax revenues so that they can make more appropriate regulations for tax provisions.

World Bank has decided that the standard deserve of its treshold tax ratio is $15 \%$. Surprisingly, Indonesia reveals below standard of tax ratios amounted 11\% from 2012 until 2015 and decrease to $10 \%$ in 2016. A below standard of tax ratio indicates the action of avoiding tax. On the other words, the phenomenon of tax avoidance in Indonesia is quite high and hence it becomes the issue for the state. Additionally, tax avoidance issue is not only happening in Indonesia, as it is also raised as main issue in ASEAN countries as well as other countries, such as; China, Germany and Europe (Ministry of Finance of the Republic of Indonesia, 2017).

Research on the relationship between corporate social responsibility and tax avoidance has been studied before by several researchers including Watson, (2012) and Lanis \& Richardson (2012). It founds that the higher corporate social responsibility disclosure of a company, the lower the level of tax aggressiveness. However, Sikka (2010) believed that the company who performs tax avoidance is classified as the organized hypocrisy company regardless they report their corporate social responsibility or not. In contrast with Lanis \& Richardson (2012), Davis et al, (2013) argued that corporate social responsibility can be seen as the mechanism to maximize firm value. Thus, there is positive correlation between corporate social responsibility and tax avoidance since tax avoidance is also seen as mechanism to maximize firm value. Presently, the research scope between corporate social responsibility and tax avoidance is unclear. This encourages an investigation into the origin of and linkages between taxation and corporate social responsibility. Thus, looking for the literature on tax avoidance and corporate social responsibility is the thrust of this research.

Moreover, there are several previous studies found that corporate governance might affect the tax avoidance, such as the size of the board of commissioners (Pratama, 2017). The higher incentive compensation tend to reduce the level of tax avoidance by the good corporate governance (Desai \& Dharmapala, 2006). Based on Lanis \& Richardson (2015), they used several corporate governance aspects as the control variable that can reduce the tax avoidance. Armstrong et al, (2012) found that the incentive of tax directors is negatively associated with the effective tax rate. However, there is few attention on the basis of some unobserved characteristics (e.g., executive risk either risk taker or risk averse).

The study that conducted by Dyreng et al, (2010) found that the executives as the individual have an important role in setting up the level of tax avoidance that firms carried out. However, this result has not provided answers about which character or behavior of individuals that influence corporate tax avoidance. The character or behavior of the executive in making the decision could be a risk taker (Low, 2006), otherwise, risk-averse (Lewellen, 
2003). The type of individual executive character whether they are risk-taking or risk-averse is reflected in the large-small corporate risk exist (Lewellen, 2003; Low, 2006). Thus, this research was directed to fill the gap from the past research that did not concern about the risk preferences executive that can influence the relationship between corporate social responsibility disclosure towards tax avoidance.

\section{LITERATURE REVIEW}

\section{Legitimacy Theory}

According to Dowling \& Pfeffer (1975), they argued that organizations try to determine the appropriateness between the social values related with their activities and the norms of acceptable behavior in the society at large which they are part. As long as both of them are in the same track, the legitimacy of the organization could be achieved. Legitimacy disclosures could be interpreted that the organization is responsible with the specific attention that has come up relate to their operations (Deegan et al, 2002). Organizations must continually attempt to ensure that they carry out activities in accordance with social boundaries and norms (Rawi \& Muchlish, 2010; Rustiarini, 2011). In addition, legitimacy theory is one of the most mentioned theories in the social and environmental accounting field (Tilling, 2004). As well Naser et al, (2006) stated that in the accounting research usually used the legitimacy theory to expand social and environmental responsibility disclosure literature. Based on this theory, the company tries to confirm its presence in society by legitimizing their activities. Company norms always change following changes from time to time so the company must follow its development. The company's efforts to follow the changes in order to gain legitimacy is a process that is carried out continuously (Suaryana, 2011). According to Hidayati \& Murni (2009), in order to survive, the company strives for a legitimacy from investors, creditors, consumers, government and the surrounding society.

\section{Stakeholder Theory}

Stakeholder theory stated that the performance of an organization is influenced by all stakeholders of the organization. Therefore, it is the managerial responsibility to provide benefits to all stakeholders that influence organizational performance (Donaldson \& Preston, 1995). According to Ghozali and Chariri (2014) in Hidayati \& Fidiana (2017) they defined that a company is not an entity which just operates for its own benefit, but should give other benefits to its stakeholders (shareholders, suppliers, creditors, government, society, employee, and other related parties).

\section{Tax Avoidance}

Taxes reflect the key part in many decisions of the corporate. Managerial policies are designed solely to decrease corporate taxes by conducting tax avoidance. It becomes a common feature that usually highly applied by the U.S Corporate to do their activities (Desai \& Dharmapala, 2009). They argued that the reason why the company avoids the tax is to transfer its value from the state to the shareholders. In line, Chen et al, (2014) conducted the research in China regarding association between tax avoidance and firm value. The result found that tax avoidance does not increase the firm value, but the benefits are gotten by the managers.

According to Xynas (2011), tax avoidance is a company's effort to reduce tax expense legally (lawful), while tax aggressiveness or tax evasion is illegally one (unlawful). Lanis \& Richardson (2011) gained the result from their research in Australia about the relationship between the composition board of director and tax aggressiveness. Tax aggressiveness is lower when the total of external board of director is bigger than the internal one (Lanis \& 
Richardson, 2011; Pratama, 2017). In addition, Armstrong et al, (2012) found that the higher independence of the board of directors, the higher financial capability about lower tax avoidance. This issue is still being considered in recent years since Lanis et al, (2017) conducted a further research by considering the female directors. The result shows a negative association between the female in the board of directors and tax aggressiveness.

\section{Corporate Social Responsibility}

Corporate social responsibility has a similar meaning with the terms of 'corporate citizenship', 'corporate sustainability' and 'triple ibottom line'. Corporate citizenship explained the firm's commitment along with stakeholders and shareholders. Then, corporate sustainability indicated the corporate behavior which is likely to affect going concern and development. Last, the triple bottom line usually defines the balance and equal promotion from the aspect of economic, social and environmental interests of a business (Bichta, 2003). The companies must engage with range of stakeholders whose looks on the company's success in many ways if the company itself want to survive and create more profit.

\section{Risk Preferences Executive}

Based on Low (2006), in carrying out its duties as the executive director of the company has two characters namely risk taker and risk-averse. Executives who have the character of risk-takers are executives who are braver in taking business decisions and usually have a stronger urge to have higher income, position, welfare, and authority (Maccrimmon \& Wehrung, 1990). As Lewellen (2003) stated that executives who are characterized as risk takers, they do not hesitate to finance debt, and hence the company can grow rapidly.

Unlike the risk takers, executives who have the risk-averse character are executives who tend to avoid the risk so they are less braver in taking the business decisions. The risk-averse executive will choose a lower risk (Low, 2006). In addition, Maccrimmon \& Wehrung (1990) argued that usually risk-averse executives have an older age, have held positions for a long time, and have a dependency with the company. Compared to the risk takers, risk-averse executives focus more on decisions that do not result in greater risk.

The research that conducted by Coles et al, (2004) stated that corporate risk is a reflection of the policy taken by the company leader. Policy taken by the company leaders can indicate whether they have risk-taking or risk-averse character. The higher the corporate risk, the more the executive has the risk taker character and vice versa.

\section{Hypotheses development}

Previous research was conducted by Lanis \& Richardson (2012; 2015), Ningrum et al, (2018), Watson (2012) to examined the association of corporate social responsibility performance with tax avoidance carried out by the company. They found that corporate social responsibility performance has a negative association with tax avoidance. In any case, Sikka (2010) stated that the organized hypocrisy company usually have the higher chance to perform tax avoidance either they are disclose their corporate social responsibility or not. Conversely with Lanis \& Richardson (2012), Davis et al. (2013) contended that corporate social responsibility can be viewed as the instrument to maximize firm value. Thus, there is positive relationship between corporate social responsibility and tax avoidance since it is also seen as an instrument to maximize firm value.

The company that disclose their corporate social responsibility integrates attention transparency of the environmental and society towards the company's operations activities and interactions along its stakeholders. If the company conduct tax avoidance, the company's reputation will be damaged in the point of the public or stakeholders view. Thus, the higher level of social responsibility disclosure conduct by the company tends to be higher the 
attitude of the responsibility of the company. Furthermore, tax and corporate social responsibility disclosure are both aimed at public welfare. The company that conduct tax avoidance are considered not socially responsible and contrary to the corporate social responsibility principles. Besides, in the point of the company's view, both tax and corporate social responsibility is classified as company's expenses. Thus, the company will choose one of them rather than conducting two expenses all at once. Therefore, the first hypothesis is formed:

\section{$H_{1}$ : Corporate social responsibility (CSR) disclosure negatively influence tax avoidance.}

In previous research, Desai \& Dharmapala (2006) have been examined the influence of high powered incentives on corporate tax avoidance. It was resulted that incentive compensation arises to be a significant influence of tax avoidance. In addition, Rego \& Wilson (2008) found the positive relationship among the agresiveness of tax and the level of executive compensation. The point of the explanation above is the management of the company tend to reduce their tax. Furthermore, the research that conducted by Dyreng et al, (2010) found that significant role of the executives in the level of tax avoidance practices by company.

As a leader in the company, the executive company has two characters in carrying out their duties namely as risk taker and risk averse (Low, 2006; Maccrimmon \& Wehrung, 1990). The higher or lower risk of the company indicates whether the executive character includes a risk taker or risk averse (Coles et al., 2004; Paligorova, 2010). Maccrimmon \& Wehrung (1990) mentioned that the executives who have the character of risk takers are the executives who are more braver in taking business decisions and usually have a stronger drive to have higher income, position, welfare, and authority.

Executives who have risk taker preferences have more courage in determining a policy even though the risk is quite high. However, risk takers with their courage are also required to produce a higher cash flow. This is done to balance the risks arising from the courage to take an action or decision. Among the various executive decisions, there are corporate tax avoidance decisions. Tax avoidance conducted by the company will affect the tax burden that must be paid to be smaller. The implications of the small tax burden that must be paid by the company will increase the company's cash flow. While, the risk-averse executive will choose a lower risk (Low, 2006). Unlike the risk takers, executives who have the risk-averse character are executives who tend to avoid the risk so they are less brave in taking the business decisions. Compared to the risk takers, risk-averse executives focus more on decisions that do not result in greater risk. Thus, they tend to be more obedient in paying taxes because they avoid the risks that will arise when the company conduct tax avoidance. Based on the description above, the second hypothesis of this research as follow:

\section{$\mathrm{H}_{2}$ : The risk preferences executive positively influence tax avoidance.}

Basically, one of the business decisions of the company is corporate tax avoidance decisions. The existence of the executives who have the character of risk taker tend to enhance the corporate social responsibility disclosure because there are several item of corporate social responsibility acitivity that practiced by the company is classified like the deductible expenses such as scholarship, environmental conservations, health program for the society, etc. The deductible expenses itself can reduce the gross income of the company and will affect the tax burden that must be paid to be smaller. The implications of the small tax burden that must be paid by the company will increase the company's cash flow. Thus, from the above explanation, the third hypothesis in this research refers: 
$H_{3}$ : The risk preferences executive positively influence the relationship between corporate social responsibility disclosure and tax avoidance.

\section{RESEARCH METHOD}

The researcher applied the purposive sampling method in this research. The sample is chosen based on the suitability of the characteristics with the specified sample criteria such as the manufacturing company that listed in IDX on 2014-2015 who disclose their corporate social responsibility disclosure, who provide financial statement that ended on $31^{\text {st }}$ December and used Indonesian currency, and never suffer loss. This select 220 company as the samples.

The dependent variable in this study is corporate tax avoidance. Tax avoidance is the company's desire to reduce the tax expense legally. This study measures the tax avoidance using the effective tax rate (ETR) by Lanis \& Richardson (2012) calculated from income tax expense divided by pre-tax income. Corporate social responsibility index (CSRI) is adapted to measure corporate social responsibility and use GRI G4.0 (Global Reporting Initiative) instrument as the indicators. According to GRI standard, it is required for the company to disclose its activities in several aspects, which are consists of economic aspect, environmental aspect, social aspect. It will be measured by total checklist, if the company discloses corporate social responsibility items is given value of 1 while if corporate social responsibility items is not disclosed it will be given value of 0 for the items already mentioned.

Risk preferences executive (RPE) is used to moderate the relationship between the corporate social responsibility and tax avoidance. The risk preferences executive is measured by the standard deviations, EBITDA (Earning before Interest, Tax, Depreciation and Amortization) is divided by the total assets of the company (Paligorova, 2010). The risk preferences executive are a dummy variable, which means if a company has a standard deviation value exceeds the average standard deviation of the entire company, it will be given a value of 1 where the leaders perform as risk taker. Companies that have a standard deviation of less than average standard deviation of the entire company will be given a value of 0, representing the leader who is risk averse (Hanafi \& Harto, 2014).

Where:

$$
\text { RISK }=\frac{\sqrt{\sum_{T=1}^{T}\left(E-\frac{1}{T} \sum_{T=1}^{T} E\right)^{2}}}{T-1}
$$

E : Earning before interest depreciation and amortization (EBITDA)/total asset

T : Total sample

The executive shares ownership controls the extent influence of the executives which own ordinary stock in the firm. The executive will also be willing to make tax avoidance decisions if he owns the company's shares. This is because the executive will also receive the impact of the efficiency of the company's tax burden. Thus, according to Armstrong et al, (2012) executive share ownership can encourage the efficiency of corporate tax payments. The executive shares is measured by the total proportion of company stock owned by the executives who serve on the board that disclosed in the annual report (Hanafi \& Harto, 2014; Irawan \& Farahmita, 2012; Lanis \& Richardson, 2015).

Besides, the executive shares ownership, the use of a Big 4 audit firm could help to reduce the practices of tax avoidance of the company by enhancing its monitoring and through a higher credibility and quality audit. Previous research found a positive correlation between Big 4 audit firm and tax avoidance, which means that companies that use Big 4 audit 
firms tend to have higher effective tax rate (Pratama, 2017). According to Lanis \& Richardson (2015) and Pratama (2017), Big 4 audit firm is measured as a dummy variable, coded 1 if the company uses a Big 4 audit firm, and 0 otherwise.

Classic assumption test is conducted to find out whether the regression model is well fitted with the research and will have no bias result. This research used 4 ways to test classic assumptions, namely multicollinearity, autocorrelation, heteroscedasticity, and normality tests.

This test is carried out using the regression analysis method or interaction test. The equation model tests hypotheses, which are as follows:

$$
\mathrm{TA}_{\mathrm{i}}=\alpha+\beta_{1} C S R D_{i}+\beta_{2} R P E_{i}+\beta_{3} C S R D_{i} * R P E_{i}+\beta_{4} E S_{i}+\beta_{5} B I G 4_{i}+\varepsilon_{i}
$$

Where:

\begin{tabular}{|c|c|c|}
\hline TA & : Tax Avoidance & \\
\hline$\alpha$ & : Constant & \\
\hline$\beta 1, \beta 2, \beta 3, \beta 4, \beta 5$ & : Coefficient Regression & \\
\hline CSRD & : Corporate Social Responsibility Disclosure & \\
\hline RPE & : Risk Preferences Executive & \\
\hline ES & : Executive Shares & \\
\hline BIG 4 & : Big 4 Audit Firm & \\
\hline CSRD*RPE & :Corporate Social & moderate by \\
\hline Preferences Executive & & \\
\hline
\end{tabular}

\section{RESULT AND DISCUSSION}

Dummy variables used in this research are the risk preferences executive and Big 4 audit firm. From 220 samples of 55 companies, there are 147 or $67 \%$ samples have the risk averse executives and 73 or $33 \%$ of samples have the risk taker executives. Meanwhile, there are 115 or $52 \%$ of samples which are audited by non Big 4 and 105 or $48 \%$ of samples are audited by Big 4.

According to Ghozali (2011), regression model can be satisfied when there is no correlation between independent variable. Multicollinearity problem does not exist when the tolerance value is $\geq 0.10$ or VIF value $\leq 10$ and hence regression model can be fulfilled. Based on the result, the tolerance value are 0.556, 0.216, 0.934, 0.838, 0.178 for each variables (CSRD, RPE, ES, BIG4, and CSRD*RPE) which are $\geq 0.10$. The VIF (Variance Inflation Factor) values are 1.800, 4.632, 1.071, 1.194, 5.633 for each variables which are $\geq$ 10. Therefore, there is no multicollinearity among the entire independent variables in the regression model.

Autocorrelation test is done to know whether there is correlation among the data of the observation. The result of Durbin Watson for autocorrelation test which is 2.149. In the Durbin Watson table with $a=5 \%$, with the sample (n) of 220 and independent variable $(\mathrm{k})$ are 5, the value of $\mathrm{dL}$ is 1.74229 and $\mathrm{dU}$ is 1.81628 . The result of Durbin Watson test fulfill the equation of $\mathrm{du}<\mathrm{d}<(4-\mathrm{du})$ because $1.81628<2.149<2.18372$.

According to Ghozali (2011), a model is free from heteroscedasticity is when the output of scatterplot does not show a specific pattern or the dots spread is anywhere. 


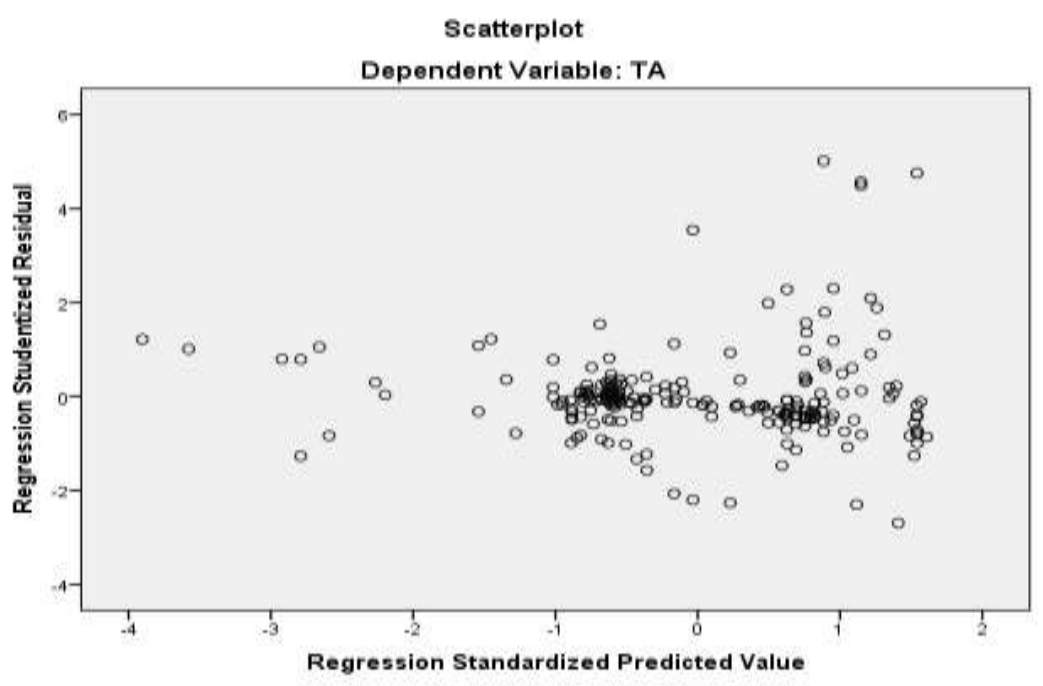

Figure 1. Heteroscedasticity Test

Based on figure 1, it can be seen that the scatterplot does not show any particular pattern. The dots inside spread everywhere that means the regression model is free from heteroscedasticity.

Normality test in this research done by looking at the significance value of KolmogorovSmirnov (K-S). The result shows the level of significant is 0.000 which is not normally distributed because the criteria of normal distribution is more than 0.05 . However, according to Hair et al, (2010) stated that the researcher must also, consider the affect of sample size. The larger sample size reduce the detrimental effects of nonnormality. Small sample is usually categorized between the range of 30-50 or even fewer observations. Especially, regression model needs at least 30 observations in general. This required significant departures from normality as this might give significant impact on the results. However, when the sample size is more than 200 observations, then the normality test may be neglected. Therefore, as this research has 220 observations that categorized in large sample, so the researcher can ignore normality test, unless it might lead to other assumption violations that do have an impact in other ways.

The adjusted $\mathrm{R}^{2}$ revealed for 0.081 and it indicates that the independent variables can explain $8.1 \%$ variation of its dependent variable, namely tax avoidance. The remaining $91.9 \%$ is explained by other variables that excluded from this research. From the ANOVA test or F test, the calculated $\mathrm{F}$ value is 4.882 with a probability of 0.000 . The probability value is smaller than 0.05 that revealed a well fitted model of regression to predict its dependent variable, namely tax avoidance by utilizing corporate social responsibility disclosure, risk preferences executive, executive shares, Big 4 audit firm, and corporate social responsibility disclosure moderated by risk preferences executive as independent variables in influencing tax avoidance simultaneously. From the result of unstandardized coefficients calculations, ES and BIG4 are not significant. It can be seen from the probability significance which are ES amounted 0.352 and BIG4 amounted 0.877. Meanwhile, CSRD is significant in 0.00, RPE in 0.006 and CSRD*RPE in 0.12. Thus, it can be concluded that TA is influenced by CSRD, RPE, and CSRD* RPE with the equations:

$$
\mathrm{TA}=0.360-0.494 \mathrm{CSRD}-0.106 \mathrm{RPE}+0.451 \mathrm{CSRD} * \mathrm{RPE}+0.001 \mathrm{ES}+0.003 \mathrm{BIG} 4
$$

\section{Interpretation Analysis}

The result shows that corporate social responsibility disclosure has significant influence towards tax avoidance since the p-value of test shows the amount of 0.000 . Therefore, it can 
be concluded that hypothesis 1 is supported. Furthermore, the result also shows negative coefficient which indicate that the higher the company disclose their corporate social responsibility the lower its effective tax rate. In other words, the more company disclose their corporate social responsibility, the more company itself practice tax avoidance since the lower effective tax rate show the higher tax avoidance.

This result is supported by prior research that conducted by Hidayati \& Fidiana, (2017) that found the higher corporate social responsibility that disclosed indicate the higher tax avoidance conducted by the company. This is because some corporate social responsible items conducted by the company are expenses that can be charged as deductible expenses, for example scholarship programs, health programs for the community, environmental conservation, support for MSMEs, and others. Thus, it cannot be denied that many companies conducted corporate social responsibilty which can be charged as a cost to reduce gross income or in other words to maximize firm value (Davis et al., 2013). In addition, companies that conducted social responsibility solely only use socially responsible actions to be able to obtain a positive image so that companies can cover their socially irresponsible actions such as tax avoidance.

The regression result of the influence of the risk preferences executive toward tax avoidance shows that the risk preferences executive has significant influence towards tax avoidance since the $\mathrm{p}$-value of test shows the amount of 0.006. Thus, it can be interpreted that the hypothesis 2 is supported (H0 is rejected). Furthermore, the results also show negative coefficient which means that the more risk taker of executives, the higher possibility of the company to perform tax avoidance.

Hanafi \& Harto (2014) shows the similar result which stated the risk taker executives tend to do corporate tax avoidance. If the executives of the company are risk takers, the greater tax avoidance will be conducted in order to pay the minimum taxes (Tandean \& Winnie, 2016). As the company's decision maker, the executive must consider several aspects before taking actions in order to get the best decision and it also includes corporate tax avoidance's decision. Dyreng et al, (2010) also supports the research result, in which the executive has a significant role in the corporate tax avoidance.

The risk preferences executive as moderating variable in this regression model reveals a significant influence of corporate social responsibility disclosure moderated by risk preferences executive towards tax avoidance. The significance value of test is amounted 0.012. The result proves that risk preferences executive weaken the relationship between corporate social responsibility disclosure and tax avoidance, since the result of significance value of relationship between corporate social responsibility disclosure and tax avoidance moderate by risk preferences executive is smaller than the non-existance of risk preferences executive. The executives have the capabilities to propose company's business decisions includes corporate tax avoidance decisions. As a risk taker of executive character, they tend to enhance the corporate social responsibility disclosure in order to hide the tax avoidance that conducted by the company itself. The implications of the small tax burden that must be paid by the company will increase the company's cash flow.

Regression test result proves that the executives shares has no significant influence on tax avoidance since the $\mathrm{p}$-value of $\mathrm{t}$-test is higher than $\alpha=5 \%$ which is 0.352 . It means that, regardless the executive own how many shares in the company, it cannot give influence to the tax avoidance that conducted by the company. This result is similar with the previous research by Lanis \& Richardson (2015) which found there is no association between the shares own by the executive and tax avoidance conducted by the company.

When the shares of the company owned by the executives, they do not want to perform tax avoidance because to their point of view they might receive higher benefit by not conducting tax avoidance rather than conducting tax avoidance. By not conducting tax 
avoidance, the interest of the investor tend to be higher thus it can attract the investor to invest in their company. Therefore, it can enhance the company's stock price and the executives can get the capital gain. Besides, the capital gain can also affect the increase in profit so that it will increase the dividend payment.

Another control variable in this research is Big 4 audit firm. The result shows that Big 4 audit firm has no significant influence toward tax avoidance. The significant value amounted 0.877 which is higher than $\alpha=5 \%$. This result also in line with the previous research by Lanis \& Richardson (2015). Furthermore, according to N. Hidayati \& Fidiana, (2017) who conducted this study in Indonesia found that there is no relationship between the quality of audit conducted by Big 4 audit firm or non Big 4 audit firm on tax avoidance.

This happens due to there has been an improvement in audit quality of non Big 4 audit firm as an implication of Chairman of Financial Service Authority and Financial Institutions Decisions No.Kep-41/BL $/ 2008$ concerning the registration of accountants conducting activities in the capital market. This regulation was issued to improve the independence, objectivity and professionalism of accountants so that it can indirectly improve the audit quality of audit firm, including non Big 4 audit firm. Therefore, regardless the company is being audited by the Big 4 audit firm or even non Big 4 audit firm, it does not affect its own company's tax avoidance.

\section{CONCLUSIONS AND LIMITATIONS}

This study examines the influence of corporate social responsibility disclosure and corporate governance towards tax avoidance as well considering its corporate governance as moderation variable in order to find the role of corporate governance in controlling corporate social responsibility disclosure towards tax avoidance. The indicator for corporate governance is risk preferences executive that employed as independent and moderate variable. This research also employs control variables to determine tax avoidance, those are; executive shares and Big 4 audit firm. Manufacturing company is chosen as the sample of this study, which is listed in Indonesia Stock Exchange for the period 2014-2017 with 220 total samples. Tax avoidance is measured using effective tax rate; GRI G4.0 index scoring will adopted to measure corporate social responsibility disclosure; dummy scoring will be used to measure risk preferences executive which is 1 for risk taker and 0 for risk averse, and Big 4 which is 1 for the company audited by Big 4 and 0 for the company audited by non Big 4; and executives shares is measured by how many percentage the executives own the shares in the company. This study use regression analysis.

The research result indicates that corporate social responsibility disclosure has significant influence toward tax avoidance. Company with high disclose in doing corporate social responsibility activities engage on high tax avoidance. This is due to some corporate social responsible items that conducted by the company are expenses that can be charged as deductible expenses to reduce gross income. The risk preferences executive toward tax avoidance also shows significant influence. The more risk taker of the executives are, the higher tax avoidance that conducted by the company itself. Furthermore, the existance of the risk preferences executive tend to weaken the relationship between corporate social responsibility disclosure and tax avoidance. The implications of the small tax burden that must be paid by the company will increase the company's cash flow.

The shares owned by the executive and Big 4 audit firm found to be insignificant towards tax avoidance. There is no influence about how many shares owned by the executives on the tax avoidance that conducted by the company. In addition, Big 4 audit firm also has no significant influence toward tax avoidance. Regardless the company itself used Big 4 audit firm or non Big 4 audit firm, it does not influence the tax avoidance conducted. 
The observation period is 4 years so the sample used in this study is relatively small in terms of time series. Moreover, this study only uses samples of manufacturing companies that listed in the Indonesia Stock Exchange. Therefore, this result only appropriate for the manufacturing sector. For further research, it is expected to add years of observation so that accurate research results are obtained in the long run. Besides, further research can expand the observation company so that research can be generalized and use more specific data, so that the results of the research are more complete and accurate.

This study uses the GRI G4.0 indicator to measure the corporate social responsibility disclosure, despite only few companies in Indonesia which apply it. Thus, there is a potential to have a subjective assessment when conducting a checklist of corporate social responsibility disclosure items. Kinder, Lydenberg, and Domini (KLD) research and analytics or EIRIS indicator can be used by future research as other proxies to measure corporate social responsibility disclosure. Meanwhile, for companies in Indonesia, it is much better to start using GRI Index as indicator to disclose their corporate social responsibility activities. Since, only several companies have applied GRI standard to measure their corporate social responsibility.

This study only used little proxy of corporate governance which are risk preferences executive, executives shares, and Big 4 audit firm. Some control variables need to be added to the study to determine the tax avoidance conducted by the company such as gender of board of director, size of board of director, size of committee audit, audit quality, etc.

\section{REFERENCES}

Armstrong, C. S., Blouin, J. L., \& Larcker, D. F. (2012). the incentives for tax planning. Journal of Accounting and Economics, 53(1-2), 391-411.

Bichta, C. (2003). Corporate social responsibility - A role in government policy and regulation? The University of Bath.

Chen, X., Hu, N., Wang, X., \& Tang, X. (2014). Tax avoidance and firm value: Evidence from China. Nankai Business Review International, 5(1), 25-42.

Coles, J. L., Daniel, N. D., \& Naveen, L. (2004). Managerial Incentives and risk-taking. Journal of Financial Economics, 79(2), 431-468.

Davis A. K., Guether, D.A., Krull, L. L., \& William, B. M. (2013). Taxes and Corporate accountability reporting: Is paying taxes viewed as socially responsible? Working Paper, Lundquist College of Business, University fo Oregon.

Deegan, C., Rankin, M., \& Tobin, J. (2002). An examination of the corporate social and environmental disclosures of BHP from 1983-1997: A Test of legitimacy theory. Accounting, Auditing \& Accountability Journal, 15(3), 312-343.

Desai, M. A., \& Dharmapala, D. (2006). Corporate Tax Avoidance and High Powered Incentives. Journal of Financial Economics, 79(1), 1-42.

Desai, M. A., \& Dharmapala, D. (2009). Corporate tax avoidance and firm value. The Review of Economics and Statistics. 91(3), 537-546.

Donaldson, T., \& Preston, L. E. (1995). Stakeholder theory: Concepts, evidence, corporations and its implications. Academy of Management Review, 20(1), 65-91.

Dowling, J., \& Pfeffer, J. (1975). Organizational legitimacy: Social values and organizational behavior between the organizations seek to establish congruence. The Pacific Sociological Review, 18(1), 122-136.

Dyreng, S. D., Hanlon, M., \& Maydew, E. L. (2010). The effects of executives on corporate tax avoidance. Accounting Review, 85(4), 1163-1189.

Ghozali, I. (2011). Aplikasi analisis multivariate dengan program IBM SPSS 19 (5th ed.). 
Semarang: Badan Penerbit Universitas Diponegoro.

Hair, J. F., Black, W. C., Babin, B. J., \& Anderson, R. E. (2010). Multivariate data analysis a global perspective. (J. Partridge, Ed.) (7th ed.). PEARSON.

Hanafi, U., \& Harto, P. (2014). Analisis pengaruh kompensasi eksekutif, kepemilikan saham eksekutif dan preferensi risiko eksekutif terhadap penghindaran pajak perusahaan. Diponegoro Journal of Accounting, 3(2), 1-11.

Hidayati, N., \& Fidiana. (2017). Pengaruh corporate social responsibility dan good corporate governance terhadap penghindaran pajak. Jurnal Ilmu dan Riset Akuntansi, 6(3), 10521070

Hidayati, N. N., \& Murni, S. (2009). Pengaruh pengungkapan corporate social responsibility terhadap earningss response coefficient pada perusahaan high profile. Jurnal Bisnis Dan Akuntansi, 11(1), 1-18.

Irawan, H. P., \& Farahmita, A. (2012). Pengaruh kompensasi manajemen dan corporate governance terhadap manajemen pajak perusahaan. Simposium Nasional Akuntansi XV.

Lanis, R., \& Richardson, G. (2011). The effect of board of director composition on corporate tax aggressiveness. Journal of Accounting and Public Policy, 30(1), 50-70.

Lanis, R., \& Richardson, G. (2012). Corporate social responsibility and tax aggressiveness: An empirical analysis. Journal of Accounting and Public Policy, 31(1), 86-108.

Lanis, R., \& Richardson, G. (2015). Is corporate social responsibility performance associated with tax avoidance? Journal of Business Ethics, 127(2), 439-457.

Lanis, R., Richardson, G., \& Taylor, G. (2017). Board of director gender and corporate tax aggressiveness: An empirical analysis. Journal of Business Ethics, 144(3), 577-596.

Lewellen, K. (2003). Financing decisions when managers are risk averse. Working Paper 4438-03, 1-53.

Low, A. (2006). Managerial risk-taking behavior and equity-based compensation. The Journal of the American Taxation Association, 23(1), 1-43.

Maccrimmon, K. R., \& Wehrung, D. A. (1990). Characteristics of risk taking executives. Management Science, 36(4), 422-435.

Ministry of Finance of the Republic of Indonesia. (2017). Sri Mulyani dan Menkeu Tiongkok bahas penghindaran pajak. Retrieved November 21, 2018, from https://www.kemenkeu.go.id/publikasi/berita/sri-mulyani-dan-menkeu-tiongkok-bahaspenghindaran-pajak/

Ministry of Finance of the Republic of Indonesia. (2018). Anggaran pendapatan belanja negara 2018. Retrieved November 24, 2018, from https://www.kemenkeu.go.id/apbn2018

Naser, K., Al-Hussaini, A., Al-Kwari, D., \& Nuseibeh, R. (2006). Determinants of corporate social disclosure in developing countries: The case of Qatar. Advances in International Accounting, 19(06), 1-23.

Ningrum, A. K., Suprapti, E., \& Hidayat Anwar, A. S. (2018). Pengaruh pengungkapan corporate social responsibility terhadap tax avoidance dengan gender sebagai variabel moderasi. Jurnal Balance, 15(1), 63-71.

Paligorova, T. (2010). Corporate risk taking and ownership structure. Bank of Canada Working Paper, (3), 1-44.

Pratama, A. (2017). Company characteristics, corporate governance and aggressive tax avoidance practice: A study of indonesian companies. Review of Integrative Business and Economics Research, 6(4), 2304-1013.

Rawi, \& Muchlish, M. (2010). Kepemilikan manajemen, kepemilikan institusi, leverage, dan CSR. Simposium Nasional Akuntansi XIII Purwokerto, 1-28.

Rego, S. O., \& Wilson, R. (2008). Executive compensation, tax reporting aggressiveness, and future firm performance. Working Paper, University of Lowa, 1-50. 
Rustiarini, N. W. (2011). Pengaruh struktur kepemilikan saham pada pengungkapan corporate social responsibility. Jurnal Ilmiah Akuntansi Dan Bisnis, 6(1), 1-24.

Sikka, P. (2010). Smoke and mirrors: Corporate social responsibility and tax avoidance. Accounting Forum, 34(3-4), 153-168.

Suaryana, A. (2011). Implementasi akuntansi sosial dan lingkungan. Simposium Nasional Akuntansi XIV Aceh 2011, 1-26.

Tandean, V. A., \& Winnie. (2016). The effect of good corporate governance on tax avoidance. Asian Journal of Accounting Research, 1(1), 28-38.

Tilling, M. V. (2004). Some thoughts on legitimacy theory in social and environmental accounting. Social and Environmental Accountability Journal, 24(2), 1-6.

Watson, L. (2012). Corporate social responsibility, tax avoidance and tax agressiveness. Pennsylvania: The Pennysylvania State University.

Xynas, L. (2011). Tax planning, avoidance and evasion in Australia 1970-2010: The regulatory responses and taxpayer compliance. Revenue Law Journal, 20(1), 1-39. 